\title{
Editorial
}

\section{Endocarditis treatment}

Infective endocarditis (IE) is a severe condition with high morbidity and a high in-hospital and 5- year mortality. Part of the strategy to decrease mortality is early diagnosis, adequate antimicrobial treatment and best surgical timing as well as access to surgery. Establishing the causative pathogen is of paramount importance, and in most settings routine blood cultures are used for this purpose, although other sites may be cultured, such as distant emboli. Besides this, serological diagnosis may important in suggestive epidemiological scenarios, especially for Bartonella spp and Coxiella burnetii.

Knowing the pathogen and its sensitivity profile helps optimize antimicrobial treatment, potentially reducing adverse events related to antibiotic toxicity and prolonged use of intravenous lines. Guidelines dealing with treatment are produced every so often by experts, and pathogen-oriented antibiotic treatment guidelines are very useful, and updated regularly. However, unfortunately, guidelines are not systematically followed. Recently Tissot Dupont has reviewed this aspect researching 13 centers with expertise on managing endocarditis, with more than 50 cases/year, mostly in Europe. Despite the fact many of the experts in this centers actually are part of the panel producing the guidelines, concordance in treatment was low, especially for difficult pathogens, such as staphylococci (adherence to guidelines of 54 to $62 \%$ ) and in patients whose blood cultures were negative, especially when IE was hospital acquired (adherence to guidelines of 0 to $15 \%)$.

In Europe, the incidence of blood culture-negative IE (BCNE) has been reported to vary between $9 \%$ and $25 \%$; in middle-income countries, BCNE accounts for 23 to $69.7 \%$ of cases of IE. Therefore, BCNE occurs more frequently in developing countries and presents a major clinical challenge for diagnosis and treatment. The fact that in a large proportion of cases blood cultures do not show growth means that empirical treatment often will be continued, as no further information regarding the pathogen will be obtained. Therefore, getting empirical treatment right is very important. We propose, in the protocol published in this issue, a practical guide to empirical therapy for infective endocarditis. Our practice is in a middle income country, where viridans group streptococci are still the most frequently isolated pathogens in subacute native valve endocarditis and late onset prosthetic valve endocarditis, followed by enterococci; in acute native valve endocarditis, staphylococci predominate, especially S.aureus, whereas in early onset prosthetic valve endocarditis, coagulase negative staphylococci, Gram negative pathogens and Candida spp also occur. In this aspect, we follow the American and European guidelines, making choices to simplify and at the same time, adapt them to our local peculiarities.

Cristiane Lamas National Institute of Cardiology, Evandro Chagas National Institute of Infectious Diseases and UNIGRANRIO, Rio de Janeiro, Brasil

Peer-review: Internal Conflict of interest: None to declare Authorship: C.L.

Acknowledgement and funding: Cristiane Lamas receives a research grant from Fundacaao de Amparo a Pesquisa do Estado do Rio de Janeiro (FAPERJ; number \# E26/202.782/2015).

\section{References}

1.Baddour LM, Wilson WR, Bayer AS, Fowler VG Jr, Tleyjeh IM, Rybak MJ, et al. Infective endocarditis in adults: diagnosis, antimicrobial therapy, and management of complications Circulation 2015; 132: 1435-86.

2.Benslimani A, Fenollar F, Lepidi $H$, Raoult D. Bacterial zoonoses and infective endocarditis, Algeria. Emerg Infect Dis 2005; 11: 216-24.

3.Brandao TJ, Januario-da-Silva CA, Correia MG, Zappa $M$, Abrantes JA, Dantas AM, et al. Histopathology of valves in infective endocarditis, diagnostic criteria and treatment considerations. Infection 2016; 45: 199-207.

4.Cecchi E, Forno D, Imazio M, Migliardi A, Gnavi R, Dal Conte I, et al. New trends in the epidemiological and clinical features of infective endocarditis: results of a multicenter prospective study. Ital Heart J 2004; 5: 24956.

Address for correspondence: Cristiane Lamas, National Institute of Cardiology, Evandro Chagas National Institute of Infectious Diseases and UNIGRANRIO, Rio de Janeiro, Brasil; Email: cristianelamas@gmail.com

Received: 02.06.2018 Accepted: 03.06.2018 Copyright $@ 2018$ Heart, Vessels and Transplantation 
5.Cetinkaya Y, Akova M, Akalin HE, Ascioglu S, Hayran $\mathrm{M}$, Uzuns $\mathrm{O}$, et al. A retrospective review of 228 episodes of infective endocarditis where rheumatic valvular disease is still common. Int JAntimicrob Agents 2001; 18: 1-7.

6.De Paula DH, Tura BR, Lamas CC. Adverse events related to intravenous antibiotic therapy: a prospective observational study in the treatment of infective endocarditis. BMJ Open 2012; 2; pii: e001189. doi: 10.1136/bmjopen-2012-001189.

7.El-Kholy AA, El-Rachidi NG, El-Enany MG, Abdul Rahman EM, Mohamed RM, Rizk HH. Impact of serology and molecular methods on improving the microbiologic diagnosis of infective endocarditis in Egypt. Infection 2015;43: 523-9.

8. Ferrera C, Vilacosta I, Fernandez C, Lopez J, Olmos C, Sarria C, et al. Reassessment of blood culture-negative endocarditis: its profile is similar to that of blood culture-positive endocarditis. Rev Esp Cardiol (Engl Ed) 2012; 65: 891-900.

9.Garg N, Kandpal B, Garg N, Tewari S, Kapoor A, Goel P, et al. Characteristics of infective endocarditis in a developing country-clinical profile and outcome in 192 Indian patients, 1992-2001. Int J Cardiol 2005; 98: 25360.

10. Gould FK, Denning DW, Elliott TS, Foweraker J, Perry $J D$, Prendergast BD, et al. Guidelines for the diagnosis and antibiotic treatment of endocarditis in adults: a report of the Working Party of the British Society for Antimicrobial Chemotherapy. J Antimicrob Chemother 2012; 67: 269-89.

11. Habib G, Lancellotti P, Antunes MJ, Bongiorni MG, Casalta JP, Del Zotti F, et al. 2015 ESC guidelines for the management of infective endocarditis. Eur Heart J 2015; 36: 3075-128.

12.Koegelenberg CF, Doubell AF, Orth $H$, Reuter $H$. Infective endocarditis in the Western Cape Province of South Africa: a three-year prospective study. QJM 2003; 96: 217-25.

13.Lamas CC, Eykyn SJ. Blood culture negative endocarditis: analysis of 63 cases presenting over 25 years. Heart 2003; 89: 258-62.

14.Lamas CC, Fournier PE, Zappa M, Brandao TJ, Januario-da-Silva CA, Correia MG, et al. Diagnosis of blood culture-negative endocarditis and clinical comparison between blood culture-negative and blood culture-positive cases. Infection 2016; 44: 459-66.

15.Letaief A, Boughzala E, Kaabia N, Ernez S, Abid F, Ben Chaabane $T$, et al. Epidemiology of infective endocarditis in Tunisia: a 10-year multicenter retrospective study. Int J Infect Dis 2007; ;11: 430-3.

16. Mirabel M, Rattanavong S, Frichitthavong $\mathrm{K}$, Chu V, Kersone $P$, Thongsith $P$, et al. Infective endocarditis in the Lao PDR: clinical characteristics and outcomes in a developing country. Int J Cardiol 2015 ;180:270-3.

17. Selton-Suty $C$, Célard $M$, Le Moing $V$, DocoLecompte $T$, Chirouze $C$, lung $B$, et al . Preeminence of Staphylococcus aureus in infective endocarditis: a 1year population-based survey. Clin Infect Dis 2012; 54: 1230-9.

18. Siciliano RF, Mansur AJ, Castelli JB, Arias V, Grinberg $M$, Levison $M E$, et al. Community-acquired culturenegative endocarditis: clinical characteristics and risk factors for mortality. Int J Infect Dis. 2014; 25: 191-5.

19.Tariq M, Alam M, Munir G, Khan MA, Smego RA, Jr. Infective endocarditis: a five-year experience at a tertiary care hospital in Pakistan. Int J Infect Dis 2004; 8: 163-70.

20. Tissot-Dupont H, Casalta JP, Gouriet F, Hubert S, Salaun E, Habib G, et al, International experts' practice in the antibiotic therapy of infective endocarditis is not following the guidelines. Clin Microbiol Infect 2017; 23 :736-9.

21. Watt G, Lacroix A, Pachirat O, Baggett HC, Raoult D, Fournier $\mathrm{PE}$, et al. Prospective comparison of infective endocarditis in Khon Kaen, Thailand and Rennes, France. Am J Trop Med Hyg 2015; 92: 871-4.

22. Wei XB, Liu YH, He PC, Zhou YL, Tan N, Chen JY, et al. Combined efficacy of $\mathrm{C}$-reactive protein and red blood cell distribution width in prognosis of patients with culture-negative infective endocarditis. Oncotarget 2017; 8: 71173-80.

23. Werner M, Andersson R, Olaison L, Hogevik H. A 10year survey of blood culture negative endocarditis in Sweden: aminoglycoside therapy is important for survival. Scand J Infect Dis 2008; 40: 279-85. 